\title{
Lexico-semantic interactions during the visual and spoken recognition of homonymous Korean Eojeols*
}

\author{
Joonwoo Kim ${ }^{1} \cdot$ Kathleen Gwi-Young Kang ${ }^{1} \cdot$ Doyoung Yoo $^{2} \cdot$ Inseo Jeon $^{2} \cdot$ \\ Hyun Kyung $\mathrm{Kim}^{2} \cdot$ Hyeomin $\mathrm{Nam}^{2} \cdot$ Jiyoung Shin ${ }^{2, * *} \cdot$ Kichun Nam ${ }^{1, * * *}$ \\ ${ }^{I}$ Department of Psychology, Korea University, Seoul, Korea \\ ${ }^{2}$ Department of Korean Language and Literature, Korea University, Seoul, Korea
}

\begin{abstract}
The present study investigated the mental representation and processing of an ambiguous word in the bimodal processing system by manipulating the lexical ambiguity of a visually or auditorily presented word. Homonyms (e.g., '물었다’) with more than two meanings and control words (e.g., '고통을') with a single meaning were used in the experiments. The lemma frequency of words was manipulated while the relative frequency of multiple meanings of each homonym was balanced. In both experiments using the lexical decision task, a robust frequency effect and a critical interaction of word type by frequency were found. In Experiment 1, spoken homonyms yielded faster latencies relative to control words (i.e., ambiguity advantage) in the low frequency condition, while ambiguity disadvantage was found in the high frequency condition. A similar interactive pattern was found in visually presented homonyms in the subsequent Experiment 2. Taken together, the first key finding is that interdependent lexico-semantic processing can be found both in the visual and auditory processing system, which in turn suggests that semantic processing is not modality dependent, but rather takes place on the basis of general lexical knowledge. The second is that multiple semantic candidates provide facilitative feedback only when the lemma frequency of the word is relatively low.
\end{abstract}

Keywords: lexical ambiguity, homonym, spoken word recognition, visual word recognition, Korean Eojeol

\section{1. 서론}

인간이 여러 의미를 지닌 중의적 언어 표현을 접할 때, 이를
어떻게 받아들이고 해석하는지는 언어학과 심리학 분야를 비 롯하여 언어공학 등 인간의 언어처리와 관련한 모든 분야에서 깊은 관심의 대상이 되어 왔다. 실제로 인간은 많은 상황에서

\footnotetext{
* This research was supported by the MSIT (Ministry of Science and ICT), Korea, under the ITRC (Information Technology Research Center) support program (IITP-2020-2017-0-001630) supervised by the IITP (Institute for Information \& Communications Technology Promotion).

**shinjy@korea.ac.kr, Corresponding author

*** kichun@korea.ac.kr, Corresponding author

Received 11 October 2020; Revised 9 February 2021; Accepted 11 February 2021

(c) Copyright 2021 Korean Society of Speech Sciences. This is an Open-Access article distributed under the terms of the Creative Commons Attribution NonCommercial License (http://creativecommons.org/licenses/by-nc/4.0) which permits unrestricted non-commercial use, distribution, and reproduction in any medium, provided the original work is properly cited.
} 
중의적인 언어 표현들을 무리 없이 처리해 내는(Rodd et al., 2002) 언어처리시스템을 가지는 반면, 컴퓨터는 동일한 형식을 모두 같은 것으로 처리하므로 인간이 자연어를 이해하고 생성 하는 것보다 더 많은 중의적 상황이 발생할 수 있다(Hong, 2007). 따라서 인간이 중의성을 가진 언어 단위들을 어떻게 처 리하는지 파악하는 것은 그 언어 자체와 인간의 언어 처리 과정 을 이해하는 데 실마리를 제공해 줄 뿐 아니라, 공학적 응용을 위해서도 필요한 일이다.

언어심리학 연구에서 인간이 어휘적, 구조적 중의성을 해소 및 처리하는 데 기반이 되는 메커니즘은 활발한 연구의 대상이 되어왔다. 특히 어휘적 중의성과 관련해서는 단어의 여러 의미 가 피드백을 제공함으로써 단의어에 비해 더 빠르고 정확하게 처리된다는 중의성 이득 효과(ambiguity advantage effect)를 주 장한 견해(Borowsky \& Masson, 1996; Hino \& Lupker, 1996; Hino et al., 2006; Jastrzembski, 1981; Jastrzembski \& Stanners, 1975; Kellas et al., 1988; Millis \& Button, 1989; Rubenstein et al., 1970) 와 이와 반대로 중의어의 경우 여러 의미 후보군이 동시에 활성 화되어 선택의 과정이 필요해짐에 따라 단의어에 비해 처리를 느리고 부정확하게 한다는 비이득 효과(disadvantage effect)를 주장한 견해(Rodd et al., 2002; Wang et al., 2012) 등 크게 두 가지 의 관점이 부각되었다. 뿐만 아니라 중의성과 단어 판단 간에는 관계성이 없다는 견해(Klepousniotou \& Baum, 2007; Pexman \& Lupker, 1999) 또한 보고되기도 하였다. 본 연구에서는 시 - 청 각 양상(modality)에 따라 단어 재인 과정에서 어휘 중의성 효과 의 방향성이 달라지는지, 다른 어휘 변인이 이 효과에 어떠한 영향을 미치는지를 조사하고자 한다.

기존 연구에서 중의성의 효과에 대하여 일관적이지 않은 결 과가 보고된 연유는 크게 세 가지 측면을 들 수 있다. 첫째, 어휘 적 중의성, 혹은 어휘 다의성에 대한 정의가 다소 모호하게 이 루어졌기 때문이다(Klein \& Murphy, 2001). 일반적으로 형태가 같으나 의미가 다른 단어를 포괄하여 중의어(ambiguous word) 로 지칭하는데, 구체적으로는 다음과 같이 구분될 수 있다. 철 자가 같고 의미가 다른 동철이의어(homograph), 철자가 다르고 소리가 같지만 의미가 다른 동음이의어(homonym), 표기와 발 음이 모두 같고 의미가 다른 동음동철이의어(homonym), 그리 고 하나의 단어가 두 가지 이상의 뜻을 가지고 있는 다의어 (polysemy: words with multiple related senses) 또한 중의어의 범 주에 포함된다. 그러나 현재까지 진행된 대부분의 연구들에서 는 이처럼 다양한 유형의 어휘 중의성에 대한 고려 없이 단순히 중의성 이득 효과, 또는 비이득효과라는 측면에 초점을 맞추어 연구가 이루어져 왔다. Rodd et al.(2002)의 다의어와 동철이의 어 자극을 사용한 연구에서는 다의어에서 중의성 이득 효과가 발견된 반면 동철이의어에서 중의성 비이득 효과를 발견하였 다. 이는 다의어가 다양한 의미(word sense) 간의 공유된 표상으 로 인해 이득 효과(sense advantage)를 가지는 반면, 동철이의어 는 개별 표상된 의미(word meaning) 간 경쟁으로 인하여 비이득 효과(ambiguity disadvantage)를 가지는 것으로 해석되었다. 한 편 한국어 다의동사(verb with multiple related senses) 구절과 동
음동철 동사(homonymic verb) 구절의 특정 의미 점화를 통한 의 미성 판단 시간을 비교한 Shin et al.(2004)의 연구에서는 동음동 철 동사 구절은 점화 의미와 표적 구절의 의미가 동일한 경우 촉진 효과가, 상이한 경우 억제 효과가 나타났다. 반면 다의동 사 구절에서는 같은 효과가 나타나지 않았으며, 결과를 바탕으 로 두 유형의 동사가 심성 어휘집 내에 다르게 표상되었을 가능 성을 제기하기도 하였다. 이처럼 어휘 중의성의 효과를 설명하 기 위해서는 다양한 어휘 중의성 유형에 대한 고려, 특히 지금 까지 고려되지 못하였던 동음동철어와 다의어의 구분이 필요 하다.

둘째, 중의성 외의 빈도 요인들에 대한 통제가 미흡하게 적용 되었다는 점이다. 여러 문헌에서 단어 빈도 효과는 단어 재인에 영향을 줄 수 있는 중요한 요인 중 하나로 받아들여진다(e.g., Scarborough et al., 1977). Clark(1973)는 Rubenstein et al.(1970)이 보고한 중의성 이득 효과에 대하여 통계적 재분석을 실시하였 으나, 중의성 이득 효과가 아닌 빈도 효과만 통계적으로 유의하 다는 결과를 보고한 바 있다. 마찬가지로 Forster \& Bendnall (1976)의 연구에서는 빈도와 중의성을 변인으로 단어 판단 시간 을 비교하였으나, 빈도 효과만 통계적으로 유의하다는 결과를 보고하였다. 또한, 한국어에서는 한 단어형의 동음이의어 중 가 장 상대빈도가 높은 의미를 쓰는 비율이 $98 \%$ 에 이르는만큼 (Kang, 2005), 중의어의 다양한 의미들이 전체 빈도에서 차지하 는 비율인 상대 빈도 또한 고려의 대상이 될 수 있다(e.g., Rayner et al.,1994). 앞서 언급한 Shin et al.(2004)에서도 중의성을 가진 동사의 의미들 간 사용 빈도를 통제하지 못한 점이 한계점으로 논의되기도 하는 등 기존 연구들은 자극 선정 시 빈도 요소들을 엄밀하게 통제하지 않았다는 점이 혼재된 결과의 원인이 될 수 있다.

다음으로 한국어 중의성 관련 연구가 주로 단어 수준에서 이 루어졌다는 점이다. 단일 단어가 독립적으로 문장 내에서 사용 되는 영어와는 다르게, 교착어적 특성을 갖는 한국어에서는 다 형태소적으로 구성되는 어절 단위가 한국어 처리 과정에서 중 요한 역할을 한다(Kim, 2016). 그러나 기존 한국어 연구(Lee, 2010; Yu \& Nam, 2009)에서는 단어 수준에서의 어휘적 중의성 만을 다루고 있기 때문에 실제 발화, 산출되는 한국어의 처리 과정을 밝히는 데는 한계를 지닌다.

마지막으로, 대부분의 중의성 연구가 단일한 처리 양상, 특히 시각 단어 재인을 위주로 진행되었다는 점이다. 인간의 언어 처 리 과정은 입력 방식에 따라 크게 달라질 수 있기 때문에 시각 연구만으로는 인간의 언어 처리 전반에 대한 일반화를 하기 어 렵다. 또한 인간의 언어는 대부분의 경우 청각 채널을 통해 입 력 및 처리되므로 청각 입력 양식을 통한 인간의 언어 처리 과 정을 파악하기 위한 연구뿐 아니라 시청각 양상 간 표상 및 처 리 방식에 대한 비교 연구 또한 필요하다. 양방향 상호활성화 모형(bi-modal interactive activation model, BIAM)에 따르면, 청 각 단어 재인뿐 아니라, 시각 단어 재인 과정에서도 자소-음소 간 상호 활성화 연결을 가지며, 이는 단어 제시 직후에 자동적 으로 활성화된다(Diependaele et al., 2010; Grainger \& Jacobs, 1996; 
Grainger et al., 2005). 이를 지지하는 실험 연구에서는 시각적으 로 제시되는 자극이 실제 단어인지 여부를 판단하는 어휘 판단 과제(lexical decision task; Gainger \& Ferrand, 1994), 동음이의어 를 사용한 점화 어휘 판단 과제(primed lexical decision task; Grainger \& Jacobs, 1996)를 사용하였다. 한국어 동음이의 단어 를 사용한 사건관련전위(event-related potential, ERP) 연구 (Kwon et al., 2013)에서는 시각 단어 재인 과정 초기에 동음이의 단어의 음운 정보가 여러 의미를 활성화하여 비동음이의 단어 대비 N400 파형이 크게 나타났다는 결과를 보고하였다. 그러나 단일 양상이 아닌 시·청각 양상에서 나타나는 중의성 효과를 비 교한 연구는 부족한 실정이다.

이에 본 연구는 한국어 모국어 화자가 한국어 어절에 대한 시 청각 어휘 판단 과제를 수행할 때, 동음동철어절의 중의성 이득 효과가 나타나는지 여부를 살펴보고자 한다. 본 연구의 대상은 철자와 소리가 같고 의미가 다른 동음동철이의 어절과, 단일한 의미로만 사용되는 단의 어절이다. 또한 중의 어절의 경우 다양 한 의미들의 사용 빈도는 주관 상대 빈도가 유사하도록 통제하 는 한편, 누적 빈도(lemma frequency)를 조작하여 빈도에 따른 중 의성 효과의 차이를 살펴보고자 하였다. 중의성 문헌에서 어휘 판단 과제는 시각 단어 재인(e.g., Borowsky \& Masson, 1996, Hino \& Lupker, 1996; Hino et al., 2002; Pexman et al., 2004; Rubenstein et al., 1970)뿐 아니라 청각 단어 재인 과정(e.g., Holley-Wilcox, 1977; Mirman et al., 2010; Rodd et al., 2002)에서 의미 차원에서 의 중의성(semantic ambiguity)을 연구하는 데 사용되어왔다. 다 만 본 연구는 시청각 양상에 따른 중의성 효과를 조사하기 위해 진행한 복수의 실험에서 단어가 아닌 어절을 연구 대상으로 하 여 어절 판단 과제를 사용하였는데, 실제 발화 상황에서 화자가 듣는 단위는 일반적으로 단어에 문법형태소가 붙은 어절1에 가 깝기 때문이다. 실험 1 에서는 청각적으로 제시된 동음동철이의 어절에서 의미 수와 어절 빈도 요인이 어절 판단 시간 및 오류 율에 미치는 영향을 살펴볼 것이다. 실험 2에서는 동일한 자극 을 시각적으로 제시하였을 때 반응 패턴의 차이를 비교하고자 한다. 만일 기존 연구에 나타난 중의성 이득 효과가 나타난다면 의미 수의 주효과가 나타날 것이며, 의미 수가 많은 자극에서
어휘 판단 시간이 빠르고 정답률이 높을 것으로 예측된다. 이러 한 중의성 효과가 어휘 처리에 강하게 영향을 미치는 것으로 알 려진 빈도 요인의 영향을 받는다면, 고빈도와 저빈도 자극에서 의미 수 효과의 차이가 나타날 것으로 예상된다. 또한, 만일 시 · 청각 양상이 동일하게 음운 정보와 어휘 표상 간 강한 상호 활 성화 연결을 가진다면, 두 양상 모두에서 유사한 패턴이 나타날 것으로 예상된다.

\section{2. 실험 1: 청각 어절 판단 과제}

실험 1 에서는 청각 어절 재인에서 나타나는 중의성과 빈도의 효과를 밝히고자 하였다. 먼저 의미 수 조작을 위해 중의어 자 극은 2 개 이상의 의미를 가진 동음동철 어절을 사용하였으며, 통제 자극은 단일한 의미를 가진 어절을 사용하였다. 자극의 빈 도 조작을 위해 말뭉치에 출현한 어절의 타입 빈도를 기준으로 고빈도, 저빈도 조건을 구분하였다. 또한 자극의 길이는 3 음절 로 통제되었으며, 자극의 주관적 의미 수와 주관 사용 빈도를 별도로 진행된 주관 평정을 통해 측정하였다. 실험 1 은 어절 판 단과제를 통해 청각적으로 제시된 중의성을 가진 동음 어절의 어휘 판단 시간 및 오류율 측정을 통해 의미 수와 어절 빈도 요 인이 어절 재인에 미치는 영향을 밝히고자 하였다.

\section{1. 연구 방법}

\subsection{1. 참가자}

한국어가 모국어이고 정상 청력을 가진 만 18-39세 $(\mathrm{M}=26.4)$ 사이의 성인남녀 32 명(남 13)이 실험에 참가하였다. 실험 참가 자들은 모두 2 년 이상의 해외 거주 경험이 없었다.

\subsection{2. 실험 자극}

조건별 실험 자극의 개수는 표 1 과 같다. 실험 자극은 동음동 철이의 어절과 비중의어절로 나뉜다. 실험 자극은 총 76 개이며 동음동철이의 어절 38 개와 비중의어절 38 개이다. 동음동철이 의 어절과 비중의어절은 각각 고빈도 자극 19 개와 저빈도 자극

표 1. 실험에 사용된 자극 조건 및 예시

Table 1. Conditions and examples of experimental stimuli

\begin{tabular}{|c|c|c|c|c|}
\hline 자극종류 & 어절 유형 조건 & 빈도 조건 & 자극 예시 & 자극 수 \\
\hline \multirow{4}{*}{ 실험 자극 } & \multirow{2}{*}{ 동음동철이의어절 } & 고빈도 & 진정한 & 19 \\
\hline & & 저빈도 & 연장은 & 19 \\
\hline & \multirow{2}{*}{ 비중의어절 } & 고빈도 & 얼굴은 & 19 \\
\hline & & 저빈도 & 발휘가 & 19 \\
\hline 방해 자극 & 비어절 & - & 선깜에 & 76 \\
\hline \multicolumn{4}{|c|}{ 계 } & 152 \\
\hline
\end{tabular}

1 엄밀히 말하면 어절은 문어의 단위이므로 구어 발화의 단위라고 말할 순 없다. 구어 발화에서 문어의 어절과 가장 유사한 단위는 음운구이다. 본 연구는 동일한 자극으로 진행하는 시각 실험까지 포함하고 있으므로 시각적으로 띄어쓰기가 개입하지 않는 ‘어절’을 그 대상으로 삼았다. 이 실험 에 쓰이는 모든 자극은 하나의 어절이며 하나의 음운구이자 억양구로 발화된 것이다. 
19 개로 구성하였다. 앞서 선정한 76 개의 실험 자극에 비어절 76 개를 추가하여 총 152 개의 자극을 실험에 사용하였다.

본 실험의 실험 자극은 2 개 이상의 의미를 가진 3 음절의 한국 어 동음동철이의 어절과 1 개의 의미만을 가지는 3 음절의 비중 의 어절이다. 자극의 음절수를 3음절로 통제한 이유는 다음과 같다. 첫째, 『한국어 중의어절 사전』(Hong et al., 2000)의 표제어 2,391 개 중에서 3 음절의 중의어절이 725 개로 약 $30.3 \%$ 의 높은 비중을 차지한다. 둘째, 2 음절에 비해서 3 음절이 더 다양한 유 형의 가능성을 가지므로 목표 자극과 빈도 정보가 일치하는 통 제 자극 및 비어절 자극 선정에도 유리하다. 따라서 모든 실험 자극은 3 음절로 통제하였다.

동음동철이의 어절 자극 선정을 위해서 1,500 만 어절 규모의 세종말뭉치(Kim \& Kang, 2009)를 참고하여 2개 이상의 의미를 갖는 3 음절의 동철이의어절 목록을 추출하였다. 단, 추출 과정 에서 의존명사, 본용언과 보조용언의 차이로 인해서 의미가 2 개 이상으로 처리된 한국어 어절은 실험 참가자들이 중의성을 인지하기 어렵다고 판단하여 목록에서 제외하였다. 또한, 어간 이 같으면서 조사의 차이로 인해서 의미가 두 개 이상으로 처리 된 어절 또한 같은 이유로 목록에서 제외하였다.

해당 어절 목록에서 동철이음이의 어절과 이철동음이의 어 절을 가지는 어절을 제외하고, 출현 빈도 800 번 이상을 고빈도 로 정의하고, 출현 빈도 10 번 이하를 저빈도로 정의하여 동음동 철어절의 목록들을 재추출하였다. 고빈도는 출현 빈도를 기준 으로 그래프를 그렸을 때, 변곡점인 800 번을 기준으로 설정하 였으며(그림 1), 저빈도의 기준은 Lee(2010)을 참고하여 10번 이 하를 기준으로 설정하되, 출현 빈도 1 인 어절들은 제외하였다 2 .

이렇게 선정한 동음동철이의 어절 186 개에 대해서 주관 평정 을 실시하였다(부록 1 참고). 주관 평정에는 한국어를 모국어로 하는 20 대의 성인 남녀 20 명(남자 10 명, 여자 10 명)이 참가하였 다. 주관 평정의 목적은 해당 어절에 대해 한국어 사용자들이 가지고 있는 주관적인 의미 수와, 그 의미들의 주관 사용 빈도 를 확인하는 것이었다. 평정 참가자들은 해당 어절을 보고 떠오 르는 모든 의미들을 영어 표현이나 예문 등의 다양한 방법을 활 용하여 자유롭게 작성한 후에 각 의미마다 주관 사용 빈도를 7 점 리커트 척도 기준(1: 쓴 적이 없음, 7: 매우 자주 사용하고 아 주 친숙함)으로 측정하여 응답하였다.

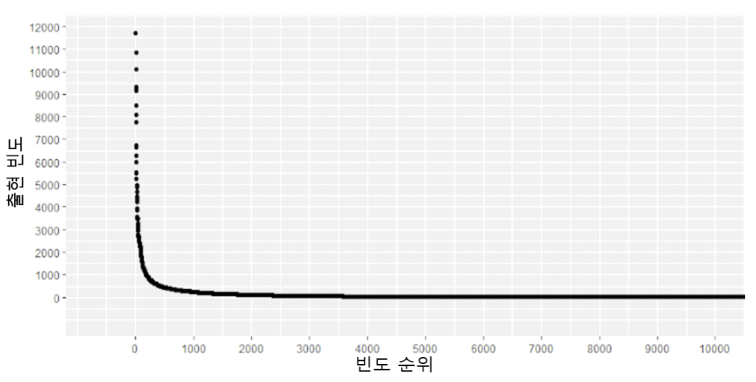

그림 1. 빈도 순위에 따른 어절의 출현 빈도

Figure 1. Frequency of target Eojeols

주관 평정 결과를 바탕으로 평정 참가자들이 생각하는 의미 수의 평균이 1.5 개 미만인 어절들은 자극 선정에서 제외하였다. 또한 각 의미들의 사용 빈도 비중인 상대 빈도의 균형을 통제하 기 위해 중의어절의 여러 의미 중 제 1 의미와 가장 적게 사용되 는 의미의 주관적 사용 빈도 간의 차이를 계산하여 평균이 3 이 상인 어절도 목표 자극에서 제외하였다. 다의어 효과를 배제하 기 위해서 국립국어원 『표준국어대사전』을 참고하여 단일 표 제어에서 파생하는 뜻풀이가 2개 이상 나타나는 다의어(word with multiple related meanings)를 포함한 어절을 자극 선정에서 제외하였다. 그 결과 최종적으로 고빈도 동음동철이의 어절 19 개와 저빈도 동음동철이의 어절 19 개가 선정되어, 총 38 개의 어 절을 동음동철이의 어절 자극으로 사용하였다.

다음으로, 비중의어절 자극선정을 위해서 $\operatorname{Kim} \& \operatorname{Kang}(2009)$ 의 연구를 참고하여 하나의 의미로만 쓰이는 3 음절의 어절 목 록을 추출하였다. 해당 어절 목록에서 이철동음이의어절을 가 지는 어절을 제외하고, 출현 빈도 800 번 이상의 고빈도 비중의 어절 목록, 출현 빈도 10 번 이하의 저빈도 비중의어절 목록들을 재추출하였다. 마찬가지로 다의어 효과를 배제하기 위해서 국 립국어원 『표준국어대사전』을 참고하여 단일 표제어에서 파생 하는 뜻풀이가 2 개 이상 나타나는 다의어를 포함한 어절은 자 극 선정에서 제외하였다. 그 후에 고빈도 비중의어절 19 개와 저 빈도 비중의어절 19 개를 무작위 추출하여, 최종적으로 총 38 개 의 어절을 비중의어절 자극으로 선정하였다.

어절 판단 과제에서 채움 항목(filler item)으로 사용된 비어절 자극은 과제의 난이도를 높이기 위해서 실제 한국어 어절과 비 슷한 유사어절 76 개를 사용하였다3. 유사어절은 한국어에서 가 능한 음운 연쇄로 이루어졌으나, 실제적인 의미가 없는 비어절 이다. 의미가 없는 2 음절 단어와 1 음절의 문법형태소를 무작위 로 결합하여 3 음절 길이의 비어절 목록을 생성하고, 그 중 표준 국어대사전 기준으로 실제로 존재하는 어절과, 철자는 다르지 만 발음이 동일하여 들었을 때 의미를 갖는 것으로 판단되는 비

2 출현 빈도가 1 회인 초저빈도 어절들은 비어절로 오인될 가능성이 있으므로 실험 자극에서 제외하였다.

3 유사어절은 실제로 한국어에 존재할 수 있는 실제 어절과 비슷한 형태를 가지는 비어절을 의미한다. 반대로 비유사어절은 한국어에 존재할 수 없 는 형태를 가지는 실제 어절과 유사도가 떨어지는 비어절을 의미한다. 비어절 자극이 실제 어절과 형태적 유사성이 높을수록 과제 난이도는 높아 진다. Pexman \& Lupker(1999)의 연구에서는 과제 난이도가 높을수록 중의성 효과를 더 쉽게 관찰할 수 있다고 보고하였다. 
어절은 목록에서 제외하였다. 또한, 한국어의 음운론적 제약을 따르지 않는 비어절도 실험 난이도를 높이기 위하여 자극 선정 에서 제외하였다4. 이러한 비어절들을 제외하고, 최종적으로 총 76 개의 유사어절을 목록에서 무작위로 추출하여 비어절 자극 으로 선정하였다(최종 자극 목록은 부록 2 참고).

실험 자극 녹음은 고려대학교 음성언어정보연구실 내 녹음 실에서 진행되었다. 위와 같은 과정으로 선정된 자극 총 152 개 를 여성 표준어 화자가 단독 산출하였고, 자극 당 평균길이는 약 $730 \mathrm{~ms}$ 였다. 한국어의 음운구는 일정한 성조 패턴이 실현되 는 단위로, Jun(2000)에 따르면 음운구의 첫 번째 음소가 마찰 음, 경음, 격음으로 시작 할 때 첫번째 음절이 고성조(high tone) 로 실현되며 그렇지 않을 때(음운구 첫번째 음소가 모음, 공명 자음, 평음일 때)에는 첫 번째 음절이 저성조(low tone)로 실현 된다. 따라서 모든 자극은 어절의 첫번째 음소에 따라 실현되어 야 할 운율로 산출될 수 있도록 고정되었다. 또한 경계 성조를 어중과 어말에서 모두 나타날 수 있는 $\mathrm{HL} \%$ 로 고정함에 따라, 자극은 각각 L.L.HL\%(저성조군), H.L.HL\%(고성조군)으로 실 현되었다. 녹음된 모든 자극은 $44,000 \mathrm{~Hz}$ 표본 추출률, $16 \mathrm{bit}$ 양 자화로 디지털화하였다.

\subsection{3. 실험 설계 및 분석}

실험은 2(어절 빈도: 고빈도 vs. 저빈도) $\times 2$ (어절 유형: 동음동 철이의 어절 vs. 단의어절) 참가자내 요인 설계로 구성되었다. 실험 데이터는 정반응에 대해서만 분석이 이루어졌으며, 실험 결과 정답률이 $80 \%$ 이하인 참가자는 분석에서 제외되었다. 참 가자내 평균 반응시간과 표준편차를 계산한 후 참가자 내 반응 시간 값이 평균 반응시간 대비 2.5 표준편차를 초과 혹은 미만인 자극, 오반응률이 $30 \%$ 를 초과하는 자극은 결측 자료로 간주하여 분석에서 제외하였다. 분석에는 반복 측정 이원 분산분석(twoway repeated measures ANOVA)이 사용되었다. 또한, 상호작용이 유의한 경우 대응표본 $t$ 검정을 통해 사후검증을 실시하였으며, 가능한 경우 본페로니 교정(Bonferroni correction)을 적용하였다. 또한, 반응시간 결과의 경우 통계 소프트웨어 R(Version 3.6.2, R Core Team, 2019)의 lme4 패키지(Version 1.1.21, Bates et al., 2015)를 사용한 선형혼합효과모형(linear mixed effect model) 분 석을 통하여 가외 변인인 품사 요인의 효과가 통제된 의미 수 및 어절 빈도 요인의 효과를 조사하고자 하였다. 고정 효과 (fixed effect)로는 실험 변인인 어절 빈도, 의미 수 요인을, 무선 효과(random effect)로는 참가자(subject)와 항목(item)을 입력하 였으며, 어절 품사 요인(동사, 명사, 형용사, 부사)은 공변량으로
포함되었다.

\subsection{4. 실험 장비 및 절차}

모든 실험은 고려대학교 심리학과 인지지각실험실 내 방음 실에서 개별적으로 이루어졌으며, 약 15 분 동안 진행되었다. 모 든 청각 자극은 Shure 사의 SRH-440 헤드폰을 통해 무작위 순서 로 제시되었으며, 자극이 제시되는 동안 삼성 사의 Samtron 77E CRT 모니터의 중앙에 고정점이 제시되었다. 참가자가 실험실 에 도착하면 충분한 설명과 안내를 통해 참가자들이 실험 절차 를 숙지하도록 한 후, 실험 동의서를 작성하도록 하였다. 본 시 행에 들어가기에 앞서 연습 시행을 실시하였으며, 여기에는 본 시행에 포함되지 않는 10 개의 어절 자극과 10 개의 비어절(filler) 자극이 포함되었다. 연습 시행에서는 실험 참가자에게 '맞았다' 혹은 ‘틀렸다'는 피드백을 주어 참가자가 과제를 잘 숙지할 수 있도록 하였으며, 정답률 $80 \%$ 이상을 기록하면 본 시행을 진행 하였다. 모든 실험 과제는 PsychoPy 1.90.2를 통해 구성되었다.

실험 1 에 사용된 과제는 청각 어절판단과제로, 헤드폰으로 자극을 듣고 한국어 어절인지 아닌지 판단하는 실험이었다(그 림 2). 먼저 청각 신호(auditory cue)인 “삐” 소리가 $300 \mathrm{~ms}$ 동안 제시된 후 간격(interval)후 청각 자극이 제시되면 실험 참가자 가 해당 자극이 어절인지 아닌지를 키보드를 눌러 판단한다. 이 때, 역균형화(counterbalancing)를 위해 실험 참가자의 절반인 16 명은 오른손 반응(어절일 경우 컴퓨터 키보드의 ‘/'키를, 비어절 일 경우 컴퓨터 키보드의 ' $\mathrm{z}$ '키를 누르도록)을, 나머지 16 명은 왼손 반응(어절일 경우 컴퓨터 키보드의 ' $z$ ' 키를, 비어절일 경우 컴퓨터 키보드의 ‘'키를 누르도록)을 하도록 지시받았다. 실험 참가자가 $3,000 \mathrm{~ms}$ 이내로 반응하지 않으면 자동으로 다음 자극 으로 넘어가도록 설계되었다. 시행 사이(inter-trial interval, ITI) 에 평균 $1,500 \mathrm{~ms}$ 의 간격을 두었으며, 또한 청각 신호와 자극 사 이의 간격 길이도 평균 $200 \mathrm{~ms}$ 로 했다5. 각 시행 중에는 검은색 바탕에 흰색 글씨로 ‘+' 표시(고정점)가 지속적으로 제시되었 고, 시행 사이(ITI)에는 검은 바탕의 화면(blank)이 나타났다.

4 예를 들어서, 조사 ‘는’은 받침이 없는 체언과만 결합하며, 받침이 있는 체언과는 결합하지 않는다. 따라서 ‘학온는', ‘홀암는’과 같은 비어절은 한 국어의 음운론적 환경 제약을 따르지 않는 비어절이므로 자극 목록에서 제외하고, ‘식움과', ‘이즌과'와 같은 자극을 사용하였다. 비어절 자극이 실제 존재하는 어절과 동일한 음운론적 제약을 따르지 않는 경우 참가자가 해당 자극을 비어절로 쉽게 판단할 가능성이 높아져 요구 특성이 나타 날 수 있기 때문이다.

5 시행 사이 간격(평균 $1,500 \mathrm{~ms}$ )과 청각 신호와 자극 사이의 간격(평균 $200 \mathrm{~ms}$ )은 고정되지 않고 모두 지터링(jittering)되었다. 이는 동일한 길이의 시간이 반복적으로 제시되었을 때, 참가자가 이에 익숙해져 실험 결과가 오염될 수 있는 가능성을 방지하기 위함이다. 지터링을 통하여 실험 참가 자가 실험에 계속 집중할 수 있도록 한다. 


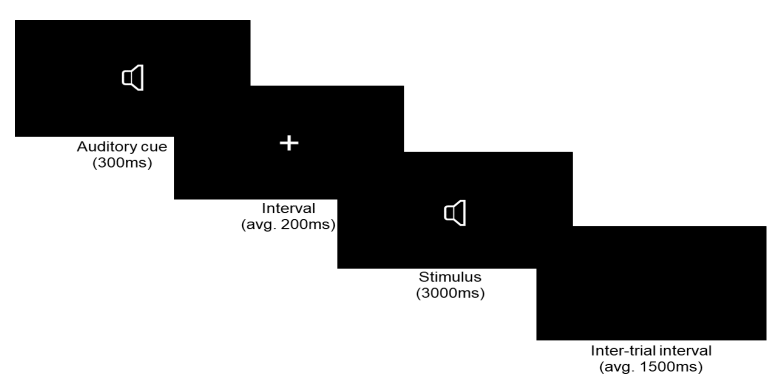

그림 2. 실험 절차. 청각 어휘 판단 과제가 사용되었으며, $300 \mathrm{~ms}$ 의 ‘삐‘소리 제시 평균 $200 \mathrm{~ms}$ 후에 청각 자극이 $3,000 \mathrm{~ms}$ 동안 제시되었으며, 자극 간 간격(inter-trial interval)은 평균 $1,500 \mathrm{~ms}$ 이었다. Figure 2. Experimental paradigm of Exp. 1 (auditory lexical decision task). A spoken stimulus $(3,000 \mathrm{~ms})$ preceded by a beep $(300 \mathrm{~ms})$ and a jittered interval (avg. $200 \mathrm{~ms}$ ). Trials were spaced with a jittered inter-trial interval of avg. 1,500 ms.

\section{2. 실험 결과}

오반응률이 $30 \%$ 를 초과하였던 9개의 어절 자극(전체 약 $11.8 \%$ )을 분석에서 제외하여 총 67 개의 어절에 대한 반응시간 과 정답률이 분석에 사용되었다. 최종적으로 분석에 사용된 자 극들의 평균 반응시간은 $1,043.60 \mathrm{~ms}$ (표준편차: $246.86 \mathrm{~ms}$ ), 전 체 실험 참가자의 정답률은 $95.2 \%$ (표준편차: $21.4 \%$ )로 조사되 었으며, 기술 통계값은 표 2에 제시되었다.

표 2. 각 조건에서 평균 반응시간 $(\mathrm{ms})$ 과 정답률 $(\%)$

Table 2. Mean reaction time (ms) and accuracy (\%)

\begin{tabular}{c|c|c|c|c}
\hline & \multicolumn{2}{|c|}{ 고빈도 } & \multicolumn{2}{c}{ 저빈도 } \\
\hline 어절 유형 & $\begin{array}{c}\text { 동음동철 } \\
\text { 이의 }\end{array}$ & 단의 & $\begin{array}{c}\text { 동음동철 } \\
\text { 이의 }\end{array}$ & 단의 \\
\hline 반응시간 & 993.15 & 959.95 & $1,106.17$ & $1,158.02$ \\
$(\mathrm{~ms})$ & $(216.20)$ & $(208.48)$ & $(240.47)$ & $(275.44)$ \\
\hline 정답률 $(\%)$ & 98.2 & 99.2 & 91.0 & 90.2 \\
\hline
\end{tabular}

반응시간에 대한 반복 측정 이원 분산분석에서 참가자별 $(F 1)$ 및 자극별 $(F 2)$ 분석에서 빈도 요인에서 조건 간 유의한 주효과 를 보였으며 $[F 1(1,30)=292.99, p<0.001 ; F 2(1,66)=110.59$, $p<0.001]$,고빈도 조건의 어절 자극에 대한 반응시간이 저빈도 조건의 어절 자극에 대한 반응시간보다 빠르게 나타났다. 의미 요인에서는 유의한 효과가 나타나지 않았지만 $[F 1(1,30)=1.26$, $p=0.26 ; F 2(1,66)=0.51, p=0.47]$, 빈도와 의미 수 두 요인 간의 상 호작용은 유의하게 나타났다 $[F 1(1,30)=22.60, p<0.001 ; F 2(1$, $66)=9.04, p<0.01]$. 빈도 조건별 대응표본 $\mathrm{t}$ 검정을 통한 사후 분석 결과 고빈도와 저빈도 조건 모두에서 의미 수 요인의 유의한 차 이가 발견되었으며 [고빈도: $t 1(31)=3.97, p<0.01$; 저빈도: $t 1(31)=-$ $3.51, p<0.01]$, 저빈도에서는 의미 수가 하나인 통제 어절 자극에 비해 동음동철이의 어절에 대한 반응 시간이 빠른 반면 고빈도 에서는 반대의 효과가 나타났다(그림 3 참고). 반응시간에 대한 선형 혼합 효과 모형 분석 결과 품사 요인은 유의한 효과가 나 타나지 않았으며 $(F=0.14, p=0.94)$, 어절 빈도의 주효과 $(F=99.08$, $p<0.001)$ 와 어절 빈도와 의미 수 요인 간 상호작용 $(F=5.11$, $p<0.05)$ 이 유의하였다.

오류율에 대한 분석 결과 참가자별 $(F 1)$ 및 자극별 $(F 2)$ 분석 모두 빈도 요인에서만 유의한 주효과가 나타났으며 $[F 1(1$, $30)=77.16, p<0.001 ; F 2(1,66)=37.67, p<0.001]$, 고빈도 조건의 어 절 자극에 대한 오류율이 저빈도 조건의 어절 자극에 대한 오류 율보다 낮게 나타났다. 반면 빈도와 의미 요인 간의 상호작용이 유의하지 않았으며 $[F 1(1,30)=0.93, p=0.33 ; F 2(1,66)=0.45$, $p=0.50]$, 의미 요인의 주효과도 나타나지 않았다 $[F 1(1,30)=0.01$, $p=0.92 ; F 2(1,66)=0.01, p=0.93]$. 오류율에 대한 선형 혼합 효과 모형 분석 결과 품사 요인과 의미 수의 주효과, 어절 빈도와 의 미 수 간 상호작용은 유의한 효과가 나타나지 않았으며(all $\mathrm{ps}>0.05)$, 어절 빈도의 주효과 $(F=-20.71, p<0.001)$ 만 유의한 것 으로 나타났다.
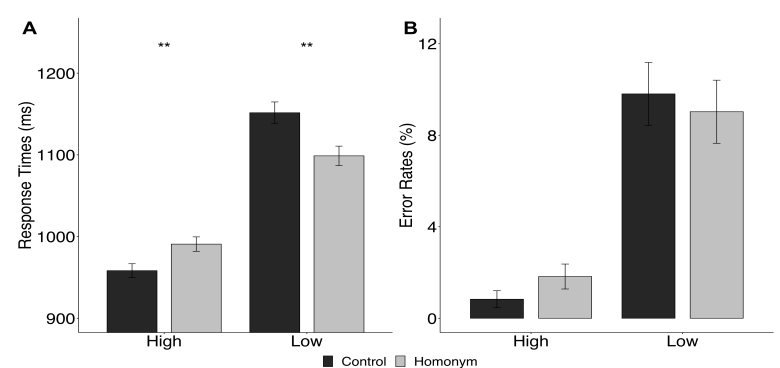

${ }^{*} p<0.05,{ }^{* *} p<0.01,{ }^{* * *} p<0.001$

그림 3. 실험 1에 나타난 조건별 평균 반응시간 (A) 및 오류율(B). 오차 막대는 평균의 표준 오차를 나타냄.

Figure 3. Mean reaction times (A) and error rates (B) for each condition in the Exp 1. Error bars represent standard error of the mean. Asterisks indicate significant post-hoc $(t$-test) results.

\section{3. 실험 2: 시각 어절 판단 과제}

실험 2에서는 실험 1에 사용된 동일한 자극을 시각적으로 제 시하였을 때 의미 수와 어절 빈도 요인이 어절 판단 수행에 미 치는 영향을 통해 자극의 양상에 따른 반응 패턴의 차이를 비교 하고자 한다. 만일 실험 1 에서 나타난 중의어 효과가 각 자극 양 상에 따라 달라진다면, 중의어 효과는 단어 재인 과정의 감각 양상(sensory modality) 의존적 처리 단계에서 나타난다고 볼 수 있고, 반면에 실험 2 의 시각 어절 재인 결과가 실험 1 의 결과와 유사하다면 감각 양상을 넘어선 공유 어휘 지식 처리에서의 효 과로 볼 수 있을 것이다.

\section{1. 연구 방법}

실험 2에서는 실험 1 에 사용된 동일한 자극을 시각적으로 제 시하였을 때 의미 수와 어절 빈도 요인이 어절 판단 수행에 미 치는 영향을 통해 자극의 양상에 따른 반응 패턴의 차이를 비교 하고자 한다.

\subsection{1. 참가자}

실험 1 에 참가하지 않았던, 한국어가 모국어이고 정상 및 교 
정 시력을 가진 만 18-39세(M=27.2) 사이의 성인남녀 32명(남 18)이 실험에 참가하였다. 실험 참가자들은 모두 2 년 이상의 해 외 거주 경험이 없었다.

\subsection{2. 실험 자극}

실험 1 과 동일한 자극이 사용되었다.

\subsection{3. 실험 설계 및 분석}

실험 1 과 동일한 설계 및 분석 방법이 사용되었다.

\subsection{4. 실험 장비 및 절차}

모든 실험은 개별적으로 이루어졌으며, 약 15 분 동안 진행되 었다. 모든 시각 자극은 삼성 사의 Samtron 77E CRT 모니터를 통해 무작위 순서로 제시되었다. 연습시행부터 본 시행까지의 과정은 실험 1 과 동일했으며, 모든 실험 과제는 실험 1 과 마찬 가지로 PsychoPy 1.90.2를 통해 구성되었다.

실험 2에 사용된 과제는 시각 어절판단과제로, 모니터 화면 에 시각적으로 제시되는 자극을 보고 한국어 어절인지 아닌지 판단하는 실험이었다(그림 4). 평균 $500 \mathrm{~ms}$ 의 간격(interval)후 시각 자극이 제시되면 실험 참가자가 해당 자극이 어절인지 아 닌지를 키보드를 눌러 판단한다. 실험 참가자가 $1,500 \mathrm{~ms}$ 이내 로 반응하지 않으면 자동으로 다음 자극으로 넘어가도록 설계 되었다. 시행 사이(ITI)에 평균 $1,500 \mathrm{~ms}$ 의 간격을 두었으며, 각 시행 처음에는 검은색 바탕에 흰색 글씨로 ‘+' 표시(고정점)가 제시되었고, 시행 사이(ITI)에는 검은 바탕의 화면(blank)이 나 타났다.

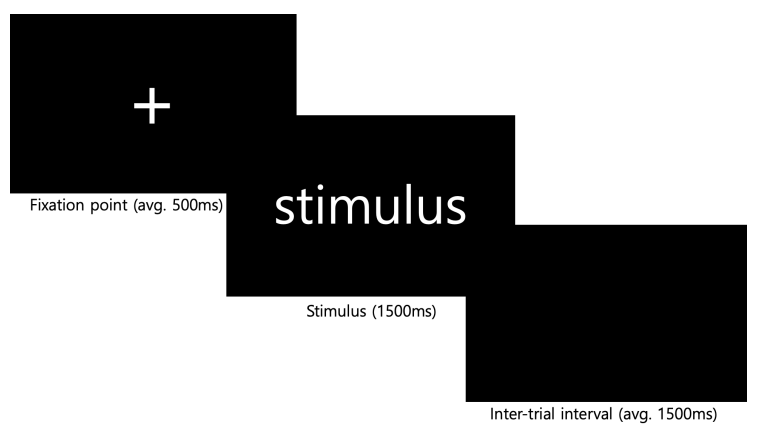

그림 4. 실험 2의 실험 절차. 시각 어휘 판단 과제가 사용되었으며, 평균 $500 \mathrm{~ms}$ 후에 시각 자극이 $1,500 \mathrm{~ms}$ 동안 제시되었으며, 자극 간 간격은 평균 $1,500 \mathrm{~ms}$ 이었다.

Figure 4. Experimental paradigm of Exp. 2 (visual lexical decision task). A visual stimulus $(1,500 \mathrm{~ms}$ ) preceded by a jittered interval (avg. $500 \mathrm{~ms})$. Trials were spaced with a jittered inter-trial interval of avg. 1,500 ms.

\section{2. 실험 결과}

실험 데이터분석은 실험 1 과 동일한 절차로 진행되었다. 전 체 자극 중 실험 1 과 같은 기준으로 분석에서 제외된 자극은 6 개 $(7.89 \%)$ 였으며, 참가자 모두가 정답률 $80 \%$ 이상을 기록하여 모든 참가자 데이터가 분석에 포함되었다. 총 70 개의 자극에 대 한 평균 반응시간은 $595.31 \mathrm{~ms}$ (표준편차 $157.51 \mathrm{~ms}$ ), 평균 정답
률은 $94.93 \%$ (표준편차 $21.95 \%$ )였으며, 최종적으로 분석에 사용 된 자극들의 기술 통계값은 표 3 에 제시된 바와 같다.

표 3. 각 조건에서 평균 반응시간 $(\mathrm{ms})$ 과 정답률 $(\%)$ Table 3. Mean reaction time (ms) and accuracy (\%)

\begin{tabular}{c|c|c|c|c}
\hline 어절 빈도 & \multicolumn{2}{|c|}{ 고빈도 } & \multicolumn{2}{c}{ 저빈도 } \\
\hline 어절 유형 & $\begin{array}{c}\text { 동음동철 } \\
\text { 이의 }\end{array}$ & 단의 & $\begin{array}{c}\text { 동음동철 } \\
\text { 이의 }\end{array}$ & 단의 \\
\hline 반응시간 & 559.82 & 546.51 & 638.98 & 654.27 \\
$(\mathrm{~ms})$ & $(130.47)$ & $(129.87)$ & $(176.59)$ & $(167.02)$ \\
\hline 정답률 $(\%)$ & 98.7 & 98.7 & 90.1 & 90.6 \\
& $(11.3)$ & $(11.3)$ & $(29.9)$ & $(29.3)$ \\
\hline
\end{tabular}

그림 5에 제시된 바와 같이, 시각 어절 판단시간에 대한 참가 자별 $(F 1)$ 및 자극별 $(F 2)$ 분석에서 빈도 요인의 유의한 주효과가 나타났으며 $[F 1(1,30)=290.90, p<0.001 ; F 2(1,66)=94.10, p<0.001]$, 고빈도 조건의 어절 자극에 대한 반응시간이 저빈도 조건의 어 절 자극에 대한 반응시간보다 빠르게 나타났다. 실험 1 과 마찬 가지로 의미 요인의 효과는 유의하지 않았지만 $[F 1(1,30)=0.01$, $p=0.90 ; F 2(1,66)=0.06, p=0.80]$, 빈도와 의미 수 요인 간의 상호 작용은 참가자별 분석에서 유의하게 나타났다 $[F 1(1,30)=5.86$, $p<0.001 ; F 2(1,66)=0.05, p=0.82]$. 빈도 조건별 대응표본 $t$ 검정을 통한 사후 분석 결과 실험 1 과 유사하게 고빈도에서는 의미 수 가 하나인 통제 어절 자극에 비해 동음동철이의 어절에 대한 반 응 시간이 느리게 나타났으며 $[t 1(31)=2.61, p<0.05]$, 저빈도에서 는 유의 수준에 근접하게 반대의 패턴이 나타났다 $[t 1(31)=-$ $1.72, p<0.10]$. 반응시간에 대한 선형 혼합 효과 모형 분석 결과 품사 요인은 유의한 효과가 나타나지 않았으며 $(F=0.13, p=0.94)$, 어절 빈도의 주효과 $(F=94.66, p<0.001)$ 만이 유의하였다.

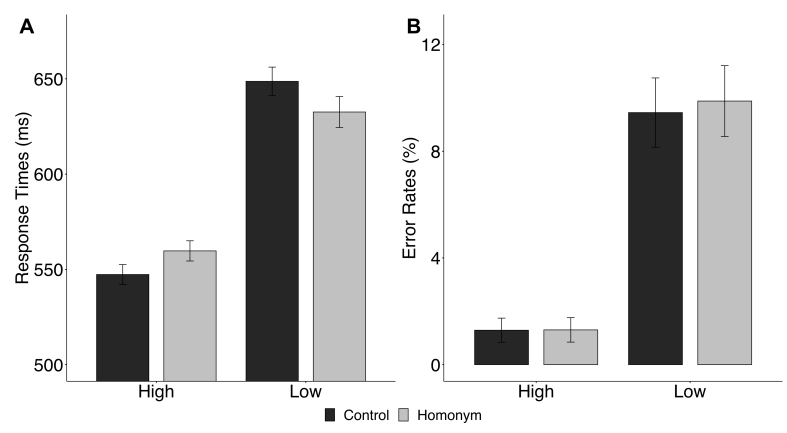

그림 5. 실험 2에 나타난 조건별 평균 반응시간 (A) 및 오류율 (B). 오차 막대는 평균의 표준 오차를 나타냄.

Figure 5. Mean reaction times (A) and error rates (B) for each condition in the Exp. 2. Error bars represent standard error of the mean.

오류율 역시 실험 1과 마찬가지로 빈도 요인에서만 유의한 주효과가 나타났으며 $(F 1[1,30]=87.08, p<0.001 ; F 2[1,66]=49.32$, $p<0.001)$, 고빈도 조건의 어절 자극에 대한 정답률이 저빈도 조 건의 어절 자극에 대한 정답률보다 높게 나타났다. 빈도와 의미 요인 간의 상호작용 $[F 1(1,30)=0.51, p=0.82 ; F 2(1,66)=0.03$, $p=0.85]$ 과 의미 요인의 주효과 $[F 1(1,30)=0.06, p=0.80 ; F 2(1$, 
66) $=0.04, p=0.84$ ]는 유의하지 않았다. 오류율에 대한 선형 혼합 효과 모형 분석 결과 품사 요인과 의미 수의 주효과, 어절 빈도 와 의미 수 간 상호작용은 유의한 효과가 나타나지 않았으며(all $\mathrm{ps}>0.05)$, 어절 빈도의 주효과 $(F=25.37, p<0.001)$ 만 유의한 것으 로 나타났다.

\section{4. 논의}

본 연구에서는 어절 빈도, 자극 양상에 따른 어휘적 중의성 효과의 차이를 비교하여 시 · 청각 언어 체계에서 의미 요인이 표상되고 처리되는 방식을 알아보고자 하였다. 어휘 중의성 유 형 중 동음동철이의어만을 선택하여 다른 유형의 중의성이 혼 입되는 것을 방지하였고, 다양한 의미 간 상대 빈도에 따른 혼 입을 방지하기 위하여 균형 동음동철이의어만을 연구 대상으 로 하였으며, 실제 발화 상황에서 화자가 듣는 단위에 가까워서 생태학적 타당성을 갖는 어절(청각 실험의 경우 하나의 음운구 이자 억양구로 발화된 어절)을 사용하였다.

연구 결과 빈도의 주효과와 더불어 빈도와 중의성의 유의한 상호작용이 발견되었다. 고빈도 어절의 경우 중의성 비이득 효 과가, 저빈도 어절의 경우 중의성 이득 효과가 나타났으며, 시 - 청각 재인 모두에서 유사한 패턴이 드러났다. 이러한 결과 는 시 · 청각 어절 처리가 유사한 표상 및 처리 방식을 거칠 가 능성을 강하게 시사한다.

한편, 두 실험 결과에서 자극의 물리적 특성에서 여러 차이가 존재하였다. 예를 들어 고정적 자극 제시 시간이 평균 $730 \mathrm{~ms}$ 로 길었던 청각 어절 재인에 소요된 평균 반응시간은 $1,043.60 \mathrm{~ms}$ 인 반면, 시각 어절 재인에 걸린 평균 반응시간은 $595.31 \mathrm{~ms}$ 로 큰 차이를 보이고 있다. 또한 반응시간-오류율 간의 관계에서도 차이를 보인다. 실험 1 에서 반응시간의 결과와 오류율은 유사 한 패턴을 보인 반면(반응시간이 길어지면 오류율도 높아졌다, 그림 3 참고), 실험 2에서는 오히려 반응시간과 오류율이 반대 의 패턴을 보이는 trade-off 현상이 나타났다. 이러한 차이는 청 각과 시각 어절의 초기 정보 처리 과정이 상당히 다르다는 것을 암시한다. 흥미로운 사실은 이러한 감각 양상 간의 큰 차이에도 불구하고 시 - 청각 어절 재인 과정 모두에서 빈도 효과와 더불 어 두 변인 간의 상호작용이 일관되게 나타났다는 것이다. 이러 한 결과는 어절의 빈도와 의미 정보의 활성화가 감각 양상 의존 적인 처리 단계에서 이루어지는 것이 아닌, 일반적 어휘 지식 처리 단계에서 이루어질 가능성을 시사한다. 또한, 이는 서론에 서 언급된 양방향 상호활성화 모형(BIAM)을 지지하는 결과로 써, 시·청각 양상 모두에서 자소-음소 간 강한 상호 활성화 연결 을 가지는 점을 시사한다.

지금까지 중의성 이득 효과를 주장했던 연구들(e.g., Hino et al., 2006; Rubenstein et al., 1970)에서는, 이 효과가 나타는 이유
를 의미가 많은 단어들은 심성어휘집(mental lexicon)에서 더 넓 게 분포해 있으므로 해당 단어를 접했을 때 더 빠른 속도로 단 어 확인을 할 수 있다고 주장하거나 의미층위에서 어휘층위로 의 피드백 때문으로 설명해 왔다. 반면에 억제 효과가 나타난다 고 주장했던 연구들(Rodd et al., 2002; Wang et al., 2012)에서는 심성어휘 안에 각각의 의미에 따라 어휘 목록이 분리되어 있다 고 보고, 중의 단어를 확인하기 위해서는 여러 의미와 어휘 목 록을 참고해야 하므로 처리 속도가 느려진다고 설명하였다. 그 런데 지금까지 보고되어 온 많은 연구들은 단어 재인에서 가장 강력한 변수로 작용할 수 있는 빈도를 엄밀하게 통제하지 않았 다. 따라서 연구 결과가 빈도 효과에 오염되었을 가능성을 배제 할 수 없는 것이다.

한편, 빈도를 통제하거나 주요 변인으로 삼은 중의성 연구들 에서는 혼재된 결과가 보고되었다. 빈도와 동음어 유형에 따른 어휘 판단 시간을 연구한 Pexman \& Lupker(1999)의 실험 2에서 는 polysemous word 조건에서 빈도와 무관한 이득 효과 ("polysemy effect"), 동음어 조건에서 빈도와 무관한 비이득 효 과(“homophone effect')를 보고하였으나, Klein \& Murphy(2001) 의 지적대로 여러 어휘 중의성 유형이 포함되어 있어 6 혼입의 가 능성을 배제하기 어렵다. 이와 유사한 맥락으로 Klepousniotou \& $\mathrm{Baum}(2007)$ 은 다의어와 동음동철이의어 조건을 구분하여 진행 한 연구에서 다의어에서는 이득 효과를 발견하였으나, 동음동 철이의어에서는 유의한 효과가 나타나지 않았다. 그러나 동음 동철이의어 조건에 사용된 자극의 평균 빈도가 100 만 어절 규 모 말뭉치(Francis \& Kucera, 1982) 기준 30-34로 고빈도였기 때 문에 본 연구에서 나타난 저빈도 동음동철이의 어절의 중의성 이득 효과를 설명하기에는 무리가 있다.

반면 본 연구 결과와 마찬가지로 단어 빈도와 의미 요인 간의 상호작용을 보고한 연구(e.g., Jastrzembski, 1981, Pexman et al., 2004)에서는 주로 저빈도에서 강한 중의성 이득 효과가 나타난 바 있다. 예시로 Pexman et al.(2004, Exp. 1)은 어휘 판단 과제를 사 용한 실험에서 고빈도 및 저빈도 동철동음이의 단어(homonym)와 단의 단어(unambiguous word)를 비교하였으며, 그 결과 저빈도 에서는 중의성 이득 효과가 나타난 반면 고빈도에서는 유의한 차이가 나타나지 않았다. 저자들은 이러한 상호작용을 철자 및 음운 수준에서의 초기 활성화가 의미 수준으로 피드포워드 (feed-forward) 방식으로 확산된 이후 다시 철자 및 음운 수준으 로 피드백(feedback) 방식으로 활성화되는 단어 재인의 병렬 분 산 처리 모형(parallel distrubted processing model; PDP model; e.g., Hino \& Lupker, 1996, Pexman et al., 2004, Seidenberg \& McClelland, 1989)7으로 설명하였다. 또한, 단어 단위를 자극으 로 사용한 위 연구들과 단어에 형태소가 결합된 형태의 어절 단 위를 자극으로 사용한 본 연구 간에 유사한 결과가 나타난 점은 이러한 상호작용이 언어 단위에 구애받지 않는 일관적 현상임

6 'Polysemy word' 조건에 bank와 같이 의미 간에 연관성이 없는 동음동철이의어(homonym, word with multiple unrelated meanings)와 watch와 같이 의 미 간에 연관이 있는 다의어(word with multiple related meanings)가 함께 포함되어 있다. 
을 시사해준다. 다음으로, 최근 뇌파(EEG), 뇌자도(MEG)와 같 은 방법으로 단어 재인 과정을 조사한 연구들에서는 뛰어난 시 간적 해상도를 바탕으로 빈도와 의미를 포함한 다양한 요인들 이 영향을 미치는 처리 단계를 보고하고 있다. 예시로 Hauk et al.(2006)은 사건관련전위(ERP)를 사용한 연구에서 시각 단어 재 인 과정의 시간대를 다양한 변인들 중 단어 빈도는 자극 제시 후 $110 \mathrm{~ms}$ 대라는 이른 시간대부터 그 효과를 보였으며, 단어의 어 휘-의미 특성(lexico-semantic property)을 반영하는 변인 semantic coherences에 따른 효과는 그보다 조금 뒤인 자극 제시 후 160 $\mathrm{ms}$ 대에 처음으로 나타났다. 이후 $300 \mathrm{~ms}$ 에서 $500 \mathrm{~ms}$ 사이에 단 어 빈도와 semantic coherence의 효과가 동시에 나타났으며, 뇌 영역 분포 상으로도 유사한 것으로 나타났다. 저자들은 이를 단 어 재인의 다단계 모형(cascaded models of word recognition; e.g., McClelland, 1979; Rogers et al., 2004)에서 제안한 처리 초기의 순차적 활성화 및 후기의 병렬적 처리와 일치하는 결과로 해석 하였다. 한편, 동음동철이의어를 사용한 MEG 연구(Simon et al., 2012)에서도 자극 제시 후 $300 \mathrm{~ms}(\mathrm{M} 350)$ 라는 유사한 시간대에 서 단어 빈도와 의미 요인의 효과가 함께 발견된 바 있다9. 따라 서 앞서 언급된 두 연구(Hauk et al., 2006; Simon et al., 2012)와 본 연구 결과를 종합해보면, 어절 재인 과정 초기 철자 및 음운 수준에서는 빈도 정보에 따라 활성화 수준의 차이가 발생하지 만, 이후 의미 수준으로의 피드포워드, 다시 철자 및 음운 수준 으로의 피드백으로 인하여 가 먼저 활성화된 이후 의미 선택 과 정으로의 피드포워드로 인하여 중의성 효과의 방향성이 달라 질 가능성을 제기할 수 있다.

다음으로, 동음동철이의어 자극을 구성하는 의미들의 빈도 에 따른 차이를 들 수 있다. 본 연구에 사용된 중의 어절은 다양 한 의미의 상대 빈도를 균일한 수준으로 통제하였으나 각 빈도 조건의 자극을 구성하는 의미 간 빈도 차이(즉 고빈도 중의 어 절을 구성하는 각 의미의 상대 빈도는 고빈도이지만, 저빈도 중 의 어절을 구성하는 각 의미의 상대 빈도가 저빈도)로 인하여 차이가 발생하였을 가능성이 존재한다. Pexman et al.(2001)에서 는 동음이의어(homophone) 목표 자극의 빈도, 목표 자극과 음이 동일하지만 철자와 의미가 다른 동음이철이의어(homophone mate)의 빈도 및 단의어의 빈도를 조작하여 어휘 판단 과제에서 나타나는 동음이의어와 단의어 간의 차이, 즉 중의성 효과를 조 사하였다 10 . 그 결과 고빈도 동음이의어는 일관적으로 단의어
대비 비이득 효과를 보였으나(실험 1-6), 저빈도 동음이철이의 어를 가지는 저빈도 목표 자극의 경우 반응시간에서 유의한 차 이가 나타나지 않았다. 저자들은 이에 대해 동음이철이의어의 음운 표상이 여러 개의 철자 표상을 활성화하고, 철자 수준으로 피드백된 표상 간에 경쟁이 발생한 것이라고 주장하였다.

반면 Hino et al.(2002), Klein \& Murphy(2001)는 동음동철이의 어와 다의어 모두에서 중의성 이득 효과를 발견하였다. Hino et al.(2002)은 이에 대해 단어가 시각적으로 제시되었을 경우 철자 표상이 음운, 의미 표상을 활성화 및 피드포워드하고, 이는 다 시 철자 및 음운을 피드백하며, 중의어의 경우 많은 의미 표상 이 활성화되므로 철자 및 음운으로의 피드백 과정이 활발하게 이루어져 이득 효과가 발생하게 된다고 주장하였다. 본 연구에 서는 다양한 의미 간 철자와 음운 표상을 공유하는 동음동철이 의어를 사용하였기 때문에 두 표상이 각각 의미와 연결되는 방 식을 설명하기는 어렵다. 그러나 Pexman et al.(2001)의 결과(고 빈도 동음이철이의어를 가지는 고빈도 목표자극)에서 볼 수 있 듯 고빈도 동음어 어절에서는 단일한 철자, 혹은 음운 표상이 활성화시키는 여러 고빈도 의미 표상이 다시 철자, 혹은 음운 표상으로 피드백하는 정보가 경쟁을 유발하여 단의어 대비 비 이득 효과를 불러올 수 있다. 저빈도 동음어 어절의 경우 여러 의미 표상의 빈도에 따라 차이가 존재하며, 본 연구에 사용된 저빈도 균형 동음동철이의어는 본질적으로 저빈도 의미 표상 들만을 가지게 되므로, Pexman et al.(2001)의 저빈도 동음이철 이의어를 가지는 저빈도 목표자극과 마찬가지로 억제 효과가 나타나지 않게 된 것이다. 그러나 본 연구에서는 저빈도 동음어 에서 반대로 단의 어절 대비 이득 효과가 나타남에 따라, 의미 단위에서 철자와 음운 단위로의 피드백 메커니즘으로 중의성 을 설명한 병렬분산처리 모형과 단어 재인의 다단계 모형에 기 반한 해석이 더 부합할 것으로 사료된다.

한편, 본 연구의 결과에는 몇 가지 제한점이 제기될 수 있다. 본 연구에서는 여러 변수들(다의어, 누적 빈도수, 의미 간 빈도 수, 어근이 같고 곡용 및 활용이 달라지는 형태 등)을 종합적으 로 고려한 결과 실험 자극에서 제외된 어절이 많았다. 자극이 여러 가지로 통제된 것이 한편으로는 연구의 완결성을 위해 반 드시 필요한 일이라고 할 수 있으나, 그 결과 자극의 수가 지나 치게 적어져 결과를 일반화하기 어려워졌다는 문제가 생긴다.

다음으로 피험자가 평정한 주관빈도를 적극적으로 결과 분

7 단어 재인의 병렬분산처리모형에서 고빈도 단어는 철자 및 음운 수준에서의 초기 휴지기(resting state)에 저빈도 단어 대비 높은 활성화를 보이며, 따라서 저빈도 단어는 초기의 비이득 효과를 보이게 된다. 그러나 저빈도 단어가 중의어일 경우, 다양한 의미 표상에서 더 큰 의미 활성화를 받고 철자 및 음운 수준으로 다시 피드백을 받게 되므로 철자 및 음운 수준에서의 약한 활성화 수준을 상쇄하게 된다.

8 Semantic coherence란 한 단어와 형태소적으로 관련된 단어들, 즉 형태소 가족(morphological family) 간의 의미적 일관성을 지칭한다. 예를 들어, $h e l p$ 의 형태소 가족(helper, helpful, helpmeet)은 높은 의미적 일관성을 가지지만, depart의 형태소 가족 중 department는 departure와 달리 낮은 의미 관련성을 가진다.

9 상호작용은 자극 제시 후 300-500 ms대의 M350 component에서 유의하게 나타났으며, 이보다 이른 시간대에 빈도 효과를 보고한 Hauk et al.(2006) 의 ERP 연구와 달리 빈도 효과는 동일한 component에서 발견되었다.

10 저빈도 동음이철이의어를 가지는 고빈도 목표 자극 $(M A D E-M A I D)$, 고빈도 동음이철이의어를 가지는 저빈도 목표 자극(MAID-MADE), 목표 자극 보다 고빈도인 동음이철이의어를 가지는 고빈도 목표 자극(FOUR-FOR), 저빈도 동음이철이의어를 가지는 저빈도 목표 자극(BAIL-BALE). 
석에 활용하지 못했다는 점이다. 본 연구에서는 어절에 대한 주 관빈도를 평정을 통해 측정하였으나 이를 의미 간 빈도 수의 균 형을 맞추기 위한 방편으로만 사용했을 뿐 주관빈도 자체를 독 립변수로 삼지 않았다. 그러나 Gernsbacher(1984), Park(2003)을 비롯한 여러 연구들에서 코퍼스에서 나타나는 출현 빈도보다 는 주관빈도가 단어에 대한 노출의 상대적 빈도를 더 잘 반영해 준다는 사실이 보고되어 왔음을 생각해 보면, 주관빈도 역시 독 립 변수로 고려할 만한 변인이라고 할 수 있다.

마지막으로, 본 연구는 생태학적 타당도를 높이기 위해 한국 어에서 주로 사용되는 어절 단위를 자극으로 선정하였으나, 단 독 발화한 어절을 청각 자극으로 사용하였다는 점이다. 또한, 경계 성조를 어중과 어말 모두에서 나타날 수 있는 $\mathrm{HL} \%$ 로 고정 하여 최대한 실제 발화에 가깝도록 노력하였으나, 의미 수를 비 롯한 다양한 어휘 변인의 통제로 인하여 자극 후보군의 수가 제 한되어 음성학 및 음향학적 특성에 대한 고려가 엄밀하게 이루 어지지 못하였다는 한계를 가진다. 추후 연구에서는 문장 단위 의 자연 발화에서 추출한 어절을 자극으로 사용함과 더불어, 음 운구의 첫 번째 음소에 따른 성조군에 대한 엄밀한 통제가 추가 로 이루어진다면 실제 발화에 가까운 청각 어절 처리 과정을 탐 구할 수 있을 것으로 기대된다.

종합하면, 본 연구 결과를 통해 한국어 어절 처리 과정에서 어휘 변인 빈도 정보가 어휘 중의성 해소 과정에 영향을 미치며, 빈도가 높은 경우 의미 선택 과정이 억제 효과를 일으키는 반면 빈도가 낮은 경우 다양한 의미 후보군은 촉진 효과를 불러온다 는 것을 알 수 있다. 특히 시 · 청각 재인 모두에서 이러한 효과 를 발견함에 따라 의미 정보의 활성화, 빈도 요인과의 상호작용 이 감각 양상 의존적 처리 단계가 아닌 어휘 지식 처리 단계에 서 이루어질 가능성을 시사한다. 또한, 본 연구에 사용된 동음 동철이의 어절은 동일한 철자 및 음운 정보를 가지는 다양한 의 미 정보가 빈도에 따라 처리 과정에 다른 피드백을 줄 수 있다 는 점을 시사하여 단순히 중의성 이득, 비이득 효과만을 설명한 기존 연구들과 구별되는 새로운 결과를 보인다.

\section{References}

Bates, D., Maechler, M., Bolker, B., \& Walker, S. (2015). Fitting linear mixed-effects models using lme4. Journal of Statistical Software, 67(1), 1-51.

Borowsky, R., \& Masson, M. E. J. (1996). Semantic ambiguity effects in word identification. Journal of Experimental Psychology: Learning, Memory, and Cognition, 22(1), 63-85.

Clark, H. H. (1973). The language-as-fixed-effect fallacy: A critique of language statistics in psychological research. Journal of Verbal Learning and Verbal Behavior, 12(4), 335-359.

Diependaele, K., Ziegler, J. C., \& Grainger, J. (2010). Fast phonology and the bimodal interactive activation model. European Journal of Cognitive Psychology, 22(5), 764-778.

Doh, J. (2018). On the ambiguity of Korean sentence: Focused on the classification of the types, Asian Cultural Studies Research Institute, 46, 39-72.

Forster, K. I., \& Bednall, E. S. (1976). Terminating and exhaustive search in lexical access. Memory and Cognition, 4, 53-61.

Francis, W. N., \& Kucera, H. (1982). Frequency analysis of English usage: Lexicon and grammar. Boston, MA: Houghton Mifflin.

Gernsbacher, M. A. (1984). Resolving 20 years of inconsistent interactions between lexical familiarity and orthography, concreteness, and polysemy. Journal of Experimental Psychology: General, 113(2), 256-281.

Grainger, J., \& Ferrand, L. (1994). Phonology and orthography in visual word recognition: Effects of masked homophone primes. Journal of Memory and Language, 33(2), 218-233.

Grainger, J., \& Jacobs, A. M. (1996). Orthographic processing in visual word recognition: A multiple read-out model. Psychological Review, 103(3), 518-565.

Grainger, J., Muneaux, M., Farioli, F., \& Ziegler, J. C. (2005). Effects of phonological and orthographic neighbourhood density interact in visual word recognition. The Quarterly Journal of Experimental Psychology Section A, 58(6), 981-998.

Hauk, O., Davis, M. H., Ford, M., Pulvermüller, F., \& MarslenWilson, W. D. (2006). The time course of visual word recognition as revealed by linear regression analysis of ERP data. Neuroimage, 30(4), 1383-1400.

Hino, Y., \& Lupker, S. J. (1996). Effects of polysemy in lexical decision and naming: An alternative to lexical access accounts. Journal of Experimental Psychology: Human Perception and Performance, 22(6), 1331-1356.

Hino, Y., Lupker, S. J., \& Pexman, P. M. (2002). Ambiguity and synonymy effects in lexical decision, naming, and semantic categorization tasks: Interactions between orthography, phonology, and semantics. Journal of Experimental Psychology: Learning, Memory, and Cognition, 28(4), 686-713.

Hino, Y., Pexman, P. M., \& Lupker, S. J. (2006). Ambiguity and relatedness effects in semantic tasks: Are they due to semantic coding? Journal of Memory and Language, 55(2), 247-273.

Holley-Wilcox, P. (1977, April). The effect of homophony with auditory presentation of stimuli. Proceedings of the 91st Annual meeting of the Midwestern Psychological Association, Chicago, IL.

Hong, J. (2007). A study on disambiguation processing in Korean machine translation. Korean Language Society, 50, 241-267.

Hong, J., Nam, K., Yoo, H., \& Lee, D., Hwang, H. (2000). Korean dictionary of ambiguous Eojeols. Seoul, Korea: Taehaksa.

Jastrzembski, J. E. (1981). Multiple meanings, number of related meanings, frequency of occurrence, and the lexicon. Cognitive Psychology, 13(2), 278-305.

Jastrzembski, J. E., \& Stanners, R. F. (1975). Multiple word meanings 
and lexical search speed. Journal of Verbal Learning and Verbal Behavior, 14(5), 534-537.

Jun, S. A. (2000). K-ToBI (Korean ToBI ) labelling conventions1. Speech Sciences, 7(1), 143-169.

Kang, B. M. (2005). Aspect of the use of homonyms. Language Research, 41(1), 1-29.

Kang, B., \& Kim, H. (2009). Frequency of Korean usage: 15 million words based on sejong form semantic analysis corpus. Seoul, Korea: Hankukmunhwasa.

Kellas, G., Ferraro, F. R., \& Simpson, G. B. (1988). Lexical ambiguity and the timecourse of attentional allocation in word recognition. Journal of Experimental Psychology: Human Perception and Performance, 14(4), 601-609.

Kim, J. (2016). Lexical factors that influence the Korean Eojeol recognition (Doctoral Dissertation). Korea University, Seoul, Korea.

Klein, D. E., \& Murphy, G. L. (2001). The representation of polysemous words. Journal of Memory and Language, 45(2), 259-282.

Klepousniotou, E., \& Baum, S. R. (2007). Disambiguating the ambiguity advantage effect in word recognition: An advantage for polysemous but not homonymous words. Journal of Neurolinguistics, 20(1), 1-24.

Kwon, Y. A., Cho, H. S., Nam, K. (2013). The event-related potential evidence of phonological activation in hangul homophone reading. Journal of Language Sciences, 20(2), 1-12.

Lee, H. Y. (2010). The representation of Korean ambiguous nouns in the mental lexicon (Master's thesis). Korea University, Seoul, Korea.

McClelland, J. L. (1979). On the time relations of mental processes: An examination of systems of processes in cascade. Psychological Review, 86(4), 287-330.

Millis, M. L., \& Bution, S. B. (1989). The effect of polysemy on lexical decision time: Now you see it, now you don't. Memory and Cognition, 17, 141-147.

Mirman, D., Strauss, T. J., Dixon, J. A., \& Magnuson, J. S. (2010). Effect of representational distance between meanings on recognition of ambiguous spoken words. Cognitive Science, 34(1), 161-173.

Park, T. (2003). Subjective frequency estimates of Korean words and frequency effects on word recognition. Korean Journal of Cognitive and Biological Psychology, 15(2), 349-366.

Pexman, P. M., \& Lupker, S. J. (1999). Ambiguity and visual word recognition: Can feedback explain both homophone and polysemy effects? Canadian Journal of Experimental Psychology, 53(4), 323-334.

Pexman, P. M., Hino, Y., \& Lupker, S. J. (2004). Semantic ambiguity and the process of generating meaning from print. Journal of Experimental Psychology: Learning, Memory, and Cognition,
$30(6), 1252-1270$.

Pexman, P. M., Lupker, S. J., \& Jared, D. (2001). Homophone effects in lexical decision. Journal of Experimental Psychology:

Learning, Memory, and Cognition, 27(1), 139-156.

R Core Team (2019). R: A language and environment for statistical computing (version 3.5.1) [Computer software]. Vienna, Austria: $\mathrm{R}$ Foundation for Statistical Computing, Retrieved from https://www.R-project.org/

Rayner, K., Pacht, J. M., \& Duffy, S. A. (1994). Effects of prior encounter and global discourse bias on the processing of lexically ambiguous words: Evidence from eye fixations. Journal of Memory and Language, 33(4), 527-544.

Rodd, J., Gaskell, G., \& Marslen-Wilson, W. (2002). Making sense of semantic ambiguity: Semantic competition in lexical access. Journal of Memory and Language, 46(2), 245-266.

Rogers, T. T., Lambon Ralph, M. A., Garrard, P., Bozeat, S., McClelland, J. L., Hodges, J. R., \& Patterson, K. (2004). Structure and deterioration of semantic memory: A neuropsychological and computational investigation. Psychological Review, 111(1), 205-235.

Rubenstein, H., Garfield, L., \& Millikan, J. A. (1970). Homographic entries in the internal lexicon 1. Journal of Verbal Learning and Verbal Behavior, 9(5), 487-494.

Scarborough, D. L., Cortese, C., \& Scarborough, H. S. (1977). Frequency and repetition effects in lexical memory. Journal of Experimental Psychology: Human Perception and Performance, 3(1), 1-17.

Seidenberg, M. S., \& McClelland, J. L. (1989). A distributed, developmental model of word recognition and naming. Psychological Review, 96(4), 523-568.

Shin, H., Choi, M. Y., \& Choi, M. (2004). Representation of Korean ambiguous verbs. Korean Society of Cognitive and Biopsychology, 16(2), 191-209.

Shin, J. Y. (2017). Prosodic markers and morphological markers in spoken Korean. Korean Linguistics, 77, 37-63.

Simon, D. A., Lewis, G., \& Marantz, A. (2012). Disambiguating form and lexical frequency effects in MEG responses using homonyms. Language and Cognitive Processes, 27(2), 275-287.

Wang, W., Li, X., Ning, N., \& Zhang, J. X. (2012). The nature of the homophone density effect: An ERP study with Chinese spoken monosyllable homophones. Neuroscience Letters, 516(1), 67-71.

Yu, G. S., \& Nam, K. C. (2009). Semantic priming effect of Korean lexical ambiguity: A comparison of homonymy and polysemy. Phonetics and Speech Science, 1(2), 63-73. 
- 김준우 (Joonwoo Kim)

고려대학교 심리학과 박사과정

서울시 성북구 안암로 145

Tel: 02-3290-2548

Email: psymon@korea.ac.kr

관심분야: 단어재인

- 강귀영 (Kathleen Gwi-young Kang)

고려대학교 심리학과 석사과정

서울시 성북구 안암로 145

Tel: 02-3290-2548

Email: kathleenkang@korea.ac.kr

관심분야: 단어재인

\section{- 유도영 (Doyoung Yoo)}

고려대학교 국어국문학과 박사과정

서울시 성북구 안암로 145

Tel: 02-3290-2505

Email: doong723@korea.ac.kr

관심분야: 음성학, 음운론

\section{- 전인서 (Inseo Jeon)}

고려대학교 국어국문학과 석사과정

서울시 성북구 안암로 145

Tel: 02-3290-2505

Email: jisisjis@korea.ac.kr

관심분야: 음성학, 음운론

\section{- 김현경 (Hyun Kyung Kim)}

고려대학교 국어국문학과 석사과정

서울시 성북구 안암로 145

Tel: 02-3290-2505

Email: doong723@korea.ac.kr

관심분야: 음성학, 음운론

\section{• 남현민 (Hyeonmin Nam)}

고려대학교 국어국문학과 석사

서울시 성북구 안암로 145

Tel: 02-3290-2505

Email: goisugn@hanmail.net

관심분야: 음성학, 음운론

- 신지영 (Jiyoung Shin) 교신저자 고려대학교 국어국문학과 교수 서울시 성북구 안암로 145

Tel: 02-3290-1973

Email: shinjy@korea.ac.kr 관심분야: 음성학, 음운론
- 남기춘 (Kichun Nam) 교신저자 고려대학교 심리학과 교수 서울시 성북구 안암로 145 Tel: 02-3290-2548

Email:kichun@korea.ac.kr 관심분야: 단어재인 
Guideline: 본 설문지는 한국어 어절의 의미 수 조사를 위한 것입니다. 한 개의 어절마다 두 가지 질문을 드립니다.

Q1. 어절을 보고 떠오르는 의미를 모두 적어주세요.

(영어, 예문 등 원하는 방식으로 자유롭게 써주시기 바랍니다.

사전에 없는 의미도 작성하실 수 있습니다.)

Q2. 각 어절에 대한 뜻과 사용 빈도를 적어 주세요. 빈도는 7점 척도입니다.

\begin{tabular}{|c|c|c|c|c|c|c|}
\hline 1 & 2 & 3 & 4 & 5 & 6 & 7 \\
\hline 쓴 적이 없음 & $\begin{array}{l}\text { 몇 번 쓴 적이 있으나 } \\
\text { 거의 사용하지 않음 }\end{array}$ & $\begin{array}{c}\text { 가꾬씩 쓰는 일이 } \\
\text { 있음 }\end{array}$ & 종종 사용함 & 퐤 자주 사용함 & 아주 자주 사용함 & $\begin{array}{c}\text { 매우 자주 사용하고 } \\
\text { 아주 친숙함 }\end{array}$ \\
\hline
\end{tabular}

\section{답변 예시}

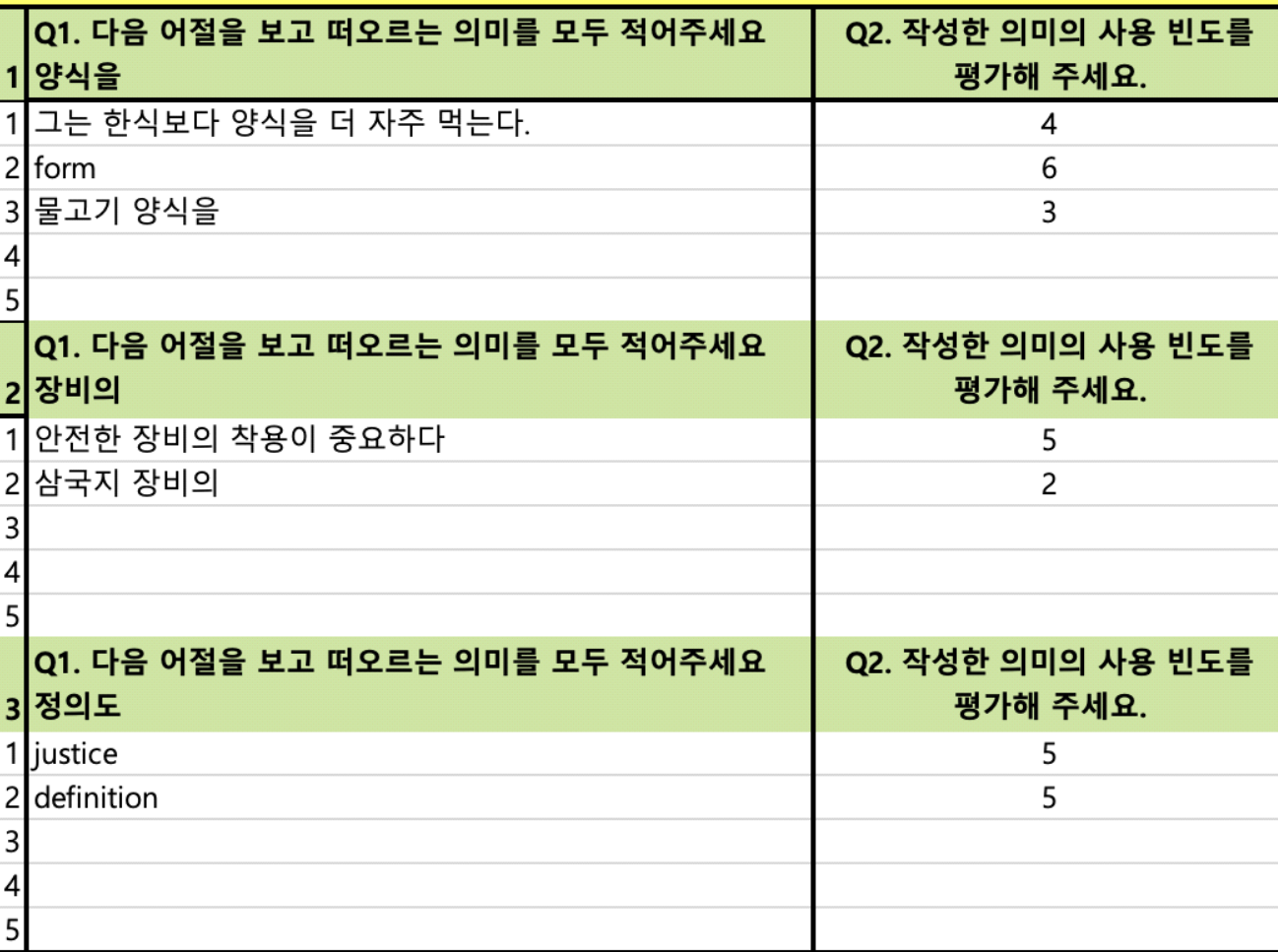




\section{부록 2. 실험 자극 목록}

\begin{tabular}{|c|c|c|c|c|}
\hline 어절 빈도 & \multicolumn{2}{|c|}{ 고빈도 } & \multicolumn{2}{|c|}{ 저빈도 } \\
\hline 어절 유형 & 동음동철이의 & 비중의 & 동음동철이의 & 비중의 \\
\hline 1 & 감정을 & 가능한 & 고령이 & 교신할 \\
\hline 2 & 고개를 & 결혼을 & 고수와 & 꽂으며 \\
\hline 3 & 그대로 & 고느롱을 & 대구서 & 논법에 \\
\hline 4 & 눈길을 & 그렇지 & 대사다 & 발휘가 \\
\hline 5 & 다음과 & 나머지 & 대치한 & 복직은 \\
\hline 6 & 되도록 & 당연히 & 말에야 & 빛나기 \\
\hline 7 & 등으로 & 드디어 & 반전에 & 선순위 \\
\hline 8 & 때까지 & 마음의 & 빵에서 & 스물도 \\
\hline 9 & 물었다 & 무서운 & 선발과 & 양면의 \\
\hline 10 & 발전을 & 변화를 & 연장은 & 양태와 \\
\hline 11 & 보이는 & 사람들 & 용지의 & 오물은 \\
\hline 12 & 사회가 & 서서히 & 전라의 & 오존을 \\
\hline 13 & 우리를 & 심각한 & 전시와 & 은화를 \\
\hline 14 & 이르는 & 심지어 & 전주가 & 잠식을 \\
\hline 15 & 작업을 & 아무리 & 조종이 & 중의문 \\
\hline 16 & 조사를 & 얼굴을 & 출연과 & 타국을 \\
\hline 17 & 주장을 & 없다는 & 설까지 & 품계에 \\
\hline 18 & 진정한 & 여자를 & 향유가 & 향취가 \\
\hline 19 & 현상을 & 의하여 & 화성과 & 확장도 \\
\hline
\end{tabular}




\title{
한국어 시·청각 동음동철이의 어절 재인에 나타나는 어휘-의미 상호작용*
}

\author{
김 준 우 ${ }^{1}$ 강 귀 영 $\cdot$ 유 도 영 $\cdot$ 전 인 서 $\cdot$ 김 현 경 $\cdot$ 남 현 민 $\cdot$ 신 지 영 $\cdot$ 남 기 춘 \\ ${ }^{1}$ 고려대학교 심리학과, ${ }^{2}$ 고려대학교 국어국문학과
}

\begin{abstract}
국문초록
본 연구는 중의성을 가진 어휘가 심성 어휘집에 표상된 방식과 감각 양상에 따른 처리 과정을 알아보기 위하여 한 국어 동음동철이의 어절의 시·청각 재인 과정을 조사하였다. 청각 어절 판단 과제(실험 1)와 시각 어절 판단 과제 (실험 2)를 이용한 두 실험에서 두 가지 이상의 의미를 가진 동음동철이의 어절(예: '물었다) 과 단일한 의미만을 가 진 통제 어절(예: '고통을')이 사용되었다. 어절 자극들의 누적 빈도는 조작하는 한편, 각 동음동철이의 어절의 다양 한 의미가 가지는 상대적 빈도는 통제하였다. 어절 판단 과제를 사용한 두 실험 모두에서 유의한 빈도의 주효과와 함께 의미 수에 따른 어절 유형과 빈도 간의 상호작용이 발견되었다. 실험 1 에서 청각적으로 제시된 동음동철이의 어절은 저빈도 조건에서 단의 어절에 비해 반응시간이 빠른 중의성 이득 효과가 나타난 반면, 고빈도 조건에서는 이와 반대로 비이득 효과가 나타났다. 마찬가지로 시각적으로 제시된 실험 2 의 자극에서도 유사한 상호작용 패턴 이 발견되었다. 본 연구 결과는 시각 및 청각 양상 모두에서 어휘-의미 처리가 상호의존적으로 이루어짐을 보여주 며, 이는 의미 처리가 감각 의존적 단계보다는 일반적 어휘 지식 처리 단계에서 이루어질 가능성을 시사한다. 이와 더불어 의미 선택 과정에서 동음동철이의 어절이 가지는 다양한 의미의 후보군은 어절의 빈도가 상대적으로 낮을 때에만 촉진적 피드백을 제공함을 보여준다.
\end{abstract}

핵심어: 어휘 중의성 , 동음동철이의어, 청각 단어 재인, 시각 단어 재인, 한국어 어절

\section{참고문헌}

강범모 (2005). 동음이의어의 사용 양상. 언어연구, 41(1), 1-29. 강범모, 김흥규 (2009). 한국어 사용 빈도: 1,500 만 어절 세종형태 의미분석말뭉치 기반. 서울: 한국문화사.

권유안, 조혜숙, 남기춘 (2013). 글 단어 읽기 이해에서 음운 정보 의 활성화: 동음이의어의 사건관련뇌파 증거. 언어과학, $20(2)$, $1-12$.

권재일, 김윤한, 문양수, 남승호, 전종호(1997). 통사 구조와 운율 구조의 상관성 연구. 언어학, 20, 59-112.

김제홍 (2016). 한국어 어절 처리에 영향을 미치는 어휘변인. 고 려대학교 석사학위논문.

남경완 (2002). 한국어 어절 중의성의 출현 양상: 어휘의 계량적 연구 방법을 통하여. 우리어문연구, 19, 353-378.

남경완, 유혜원 (2006). 동사-형용사 중의 어절의 중의성 해소 연 구: 한국어 정보 처리와 관련하여. 어문연구, 34(3), 167-189.

도재학 (2018). 국어 문장의 중의성에 대하여: 언표 및 발화 문장 에 따른 유형 분류를 중심으로. 아시아문화연구, 46, 39-72.

박종갑 (2001). 국어 부정문의 중의성에 대하여(1). 한민족어문
학, 38, 163-183.

박태진 (2003). 한국어 단어의 주관적 빈도 추정치 및 단어 재인에 미치는 빈도 효과. 한국심리학회지: 인지 및 생물, 15(2), 349-366.

신지영 (2017). 구어에서 운율 표지와 형태 표지의 분포와 기능. 한국어학, 77, 37-63.

신현정, 최미영, 최민경 (2004). 한국어 다의동사의 표상. 한국심 리학회지: 인지 및 생물, 16(2), 191-209.

유기순, 남기춘(2009). 한국어의 어휘적 중의성의 의미점화효과: 동음이의어와 다의어의 비교. 말소리와 음성과학, 1(2), 63-73. 이호영 (2010). 한국어 중의어 명사의 심성어휘 표상. 고려대학교 석사학위논문.

홍종선 (2007). 한국어 기계 번역에서의 중의성 처리 연구. 국어 학, 50, 241-267.

홍종선, 남경완, 유혜원, 이동혁, 황화성 (2008). 한국어 중의어절 사전. 서울: 태학사.

\footnotetext{
* 본 연구는 과학기술정보통신부 및 정보통신기획평가원의 대학ICT연구센터육성지원사업의 연구결과로 수행되었음(IITP-2020-2017-0-001630).
} 